\title{
PHYSICAL-CHEMICAL CHARACTERIZATION OF URANIUM CONTAINING SEDIMENTS
}

\author{
LUCIA ZÁVODSKÁ ${ }^{1}$, EVA KOSORÍNOVÁ², JURAJ LESNÝ², \\ DUŠAN BODIŠ $\breve{3}^{3}$ \\ ${ }^{1}$ Department of Nuclear Chemistry, Comenius University in Bratislava, \\ Mlynská dolina, Bratislava, SK- 842 15, Bratislava 4, Slovak Republic \\ (zavodskalucia@centrum.sk) \\ ${ }^{2}$ Department of Biotechnology, University of SS Cyril and Methodius, J. Herdu 2, \\ Trnava, SK-917 01, Slovak Republic (lesnyj@ucm.sk) \\ ${ }^{3}$ State Geological Institute of Dionýz Štúr, Mlynská dolina 1, Bratislava 11, \\ SK-817 04, Slovak Republic (dusan.bodis@geology.sk)
}

\begin{abstract}
The presented paper is intended to study the chemical behaviour of combined geogenicanthropogenic uranium content in specific stream sediments. The sampling points have been chosen with respect to the natural conditions in the locality of groundwater outflow from a former uranium mine adit in Považský Inovec mountain range, near Kálnica village. Besides the total uranium determination and physical-chemical characterization of the relevant water- and sediment samples we carried out modified Tessier type sequential fractionation extractions of natural- and artificially contaminated sediment samples after time dependent agitation in air and in the atmosphere of argon. The obtained results have been compared with those fulfilled with montmorillonite K-10. The total uranium concentrations of the relevant groundwater samples as well as of stream sediments have been determined by ICP-MS using HP 4500. The determinations of uranium in extracts have been accomplished according STN757614, utilizing arsenazo III as a selective complex forming reagent for spectrophotometric determination of uranyl-ions at $650 \mathrm{~nm}$. The total uranium concentration of the groundwater outflow and in the sediment taken in its immediate vicinity has been $31.75 \pm 0.35 \mu \mathrm{g} \mathrm{dm}^{-3}$ and $38.0 \pm 2.7 \mu \mathrm{g} \mathrm{g}^{-1}$ respectively. Unlike montmorillonit $\mathrm{K}-10$, in which the carbonate-bound fraction of uranium after 1 week aeration and agitation in argon atmosphere represents $22.8 \%$ and $18.6 \%$ respectively, uranium in investigated sediments has been present predominantly in carbonate-bound fraction-reaching under similar conditions $38.6 \%$ and $26.6 \%$, respectively.
\end{abstract}

Key words: uranium, sediments, groundwater, sequential fractionation

\section{Introduction}

Uranium is an element of highly specific chemical, physical and biological properties. Mostly because of its essentiality for nuclear energy production and its toxicity, the interest in its environmental mobility attracts constantly increasing attention. Among basic features of uranium the following ones are crucial: it is a typical lithophilic natural radioactive component of the environment and contrary to its notoriety its radiotoxicity is negligible in comparison with chemical toxicity. The substantial chemical properties of uranium decisively influencing its transport in the environment as well as its determination possibilities are outlined in our earlier papers (ZÁVODSKÁ et al., 2008; SZABÓ-NAGY et al., 2009). Uranium in natural waters may be present in four different oxidation states (U(III), U(IV), U(V) and $\mathrm{U}(\mathrm{VI})$. In general, the tetravalent and hexavalent uranium species are stable in aqueous media, but the $\mathrm{U}(\mathrm{IV})$-ion is only stable under reducing condition. A few solid and semi-metalis compounds such as UO and US exist in the formal oxidation 
state U(II), although no simple ions are known to exist in solution for that state. The most prevalent form of uranium in aqueous solution is the light yellow, fluorescent uranyl ion $\left(\mathrm{UO}_{2}^{2+}\right)$. The $\mathrm{U}^{4+}$ cation (green in solution) can be obtained by strong reduction of $\mathrm{U}(\mathrm{VI})$, but in the air it oxidizes back to $\mathrm{UO}_{2}^{2+}$. The pentavalent ion $\mathrm{UO}_{2}^{+}$can be reversibly formed by reduction of $\mathrm{UO}_{2}^{2+}$, but it readily disproportionates into $\mathrm{U}(\mathrm{IV})$ and $\mathrm{U}(\mathrm{VI})$. The trivalent $\mathrm{U}^{3+}$ can be formed by reduction of $\mathrm{U}(\mathrm{IV})$ but it is unstable as it oxidizes in aqueous solution (GREENWOOD and EARNSHAW, 1997).

\section{2. pe and $\mathrm{pH}$ dependence of $\mathrm{U}$ oxidation states in natural waters}

The thermodynamic principles of advanced aquatic chemistry including modelling methods are fairly discussed in a series of recent monographs (BENJAMIN, 2002; MOREL and HERING, 1993; GRENTHE and PUIGDOMENECH, 1997). Putting to data set the updated thermodynamic values concerning uranium hydro- and carbonate species (GUILLAUMONT et al., 2003) and utilizing the freeware PHREEQC VERSION 2.15.0 (USGS, 2008) we calculated the proportions of U(III), U(IV), U(V) and $\mathrm{U}(\mathrm{VI})$ concentrations in dependence of pe and $\mathrm{pH}$ introducing the following model conditions (Fig. 1-4): Total uranium: $0.00005 \mathrm{mmol} \mathrm{dm}^{-3}$; Alcalinity: $3.0 \mathrm{mmol}$ $\mathrm{dm}^{-3}$; Calcium: $1.5 \mathrm{mmol} \mathrm{dm}{ }^{-3}$; Temperature: $298.15 \mathrm{~K}$; Thermodynamic data:

$$
\begin{aligned}
& \mathrm{U}^{4+}+\mathrm{e}^{-}=\mathrm{U}^{3+}(\log \mathrm{K}=-9.353 ; \Delta \mathrm{H}=102.098 \mathrm{~kJ}) \\
& \mathrm{U}^{4+}+4 \mathrm{H}_{2} \mathrm{O}=\mathrm{U}(\mathrm{OH})_{4}+4 \mathrm{H}^{+} \quad(\log \mathrm{K}=-8.538 ; \Delta \mathrm{H}=103.596 \mathrm{~kJ}) \\
& \mathrm{U}^{4+}+5 \mathrm{H}_{2} \mathrm{O}=\mathrm{U}(\mathrm{OH})_{5}+5 \mathrm{H}^{+}(\log \mathrm{K}=-13.147 ; \Delta \mathrm{H}=115.395 \mathrm{~kJ}) \\
& \mathrm{U}^{4+}+2 \mathrm{H}_{2} \mathrm{O}=\mathrm{UO}_{2}^{+}+4 \mathrm{H}^{+}+\mathrm{e}^{-}(\log \mathrm{K}=-6.432 ; \Delta \mathrm{H}=130.248 \mathrm{~kJ}) \\
& \mathrm{U}^{4+}+2 \mathrm{H}_{2} \mathrm{O}=\mathrm{UO}_{2}^{2+}+4 \mathrm{H}^{+}+2 \mathrm{e}^{-}(\log \mathrm{K}=-9.217 ; \Delta \mathrm{H}=144.055 \mathrm{~kJ}) \\
& \mathrm{UO}_{2}^{2+}+\mathrm{H}_{2} \mathrm{O}=\mathrm{OU}_{2} \mathrm{OH}^{+}+\mathrm{H}^{+}(\log \mathrm{K}=-5.250 ; \Delta \mathrm{H}=46.087 \mathrm{~kJ}) \\
& 2 \mathrm{UO}_{2}^{2+}+2 \mathrm{H}_{2} \mathrm{O}=\left(\mathrm{UO}_{2}\right)_{2}(\mathrm{OH})_{2}^{2+}+2 \mathrm{H}^{+}(\log \mathrm{K}=-5.620 ; \Delta \mathrm{H}=150.791 \mathrm{~kJ}) \\
& 3 \mathrm{UO}_{2}^{2+}+5 \mathrm{H}_{2} \mathrm{O}=\left(\mathrm{UO}_{2}\right)_{3}(\mathrm{OH})_{5}^{+}+5 \mathrm{H}^{+}(\log \mathrm{K}=-15.550 ; \Delta \mathrm{H}=-185.226 \mathrm{~kJ}) \\
& \mathrm{UO}_{2}^{2+}+\mathrm{CO}_{3}^{2-}=\mathrm{UO}_{2} \mathrm{CO}_{3}(\log \mathrm{K}=9.94 ; \Delta \mathrm{H}=5.000 \mathrm{~kJ}) \\
& \mathrm{UO}_{2}^{2+}+2 \mathrm{CO}_{3}^{2-}=\mathrm{UO}_{2}\left(\mathrm{CO}_{3}\right)_{2-}^{2-}(\log \mathrm{K}=16.61 ; \Delta \mathrm{H}=8.500 \mathrm{~kJ}) \\
& \mathrm{UO}_{2}^{2+}+3 \mathrm{CO}_{3}^{2-}=\mathrm{UO}_{2}\left(\mathrm{CO}_{3}\right)_{3}^{4-}(\log \mathrm{K}=21.840 ; \Delta \mathrm{H}=-39.200 \mathrm{~kJ})
\end{aligned}
$$

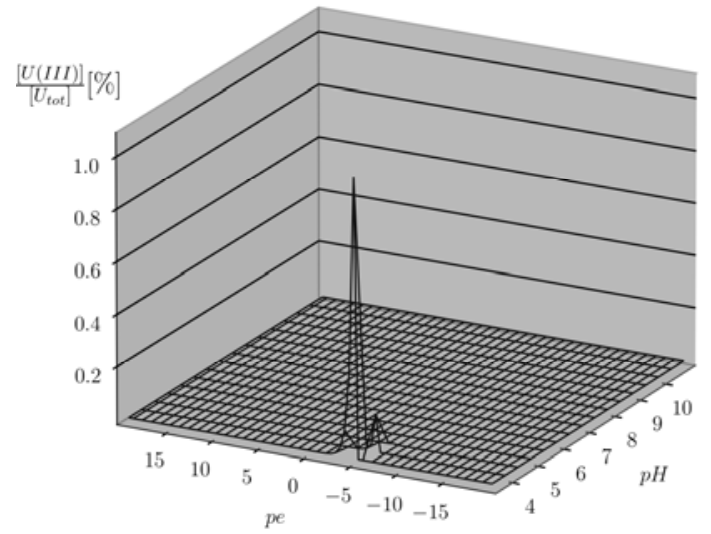

Fig. 1. Proportion of U(III) species in model natural waters in dependence of pe and pH. 


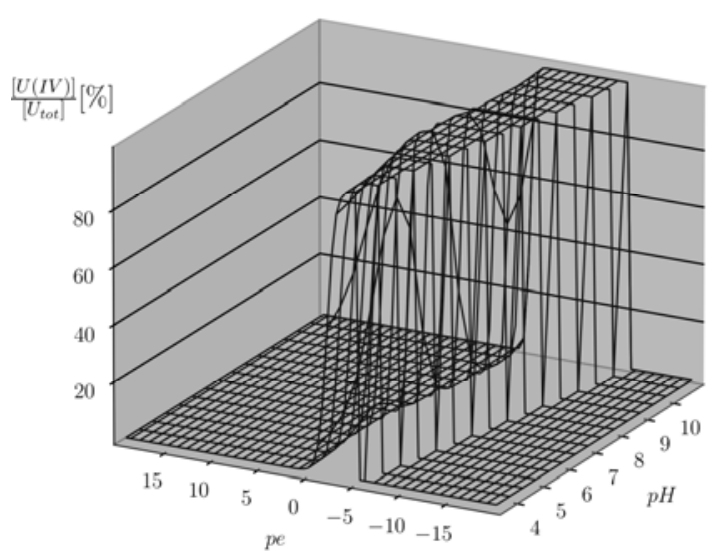

Fig. 2. Proportion of U(IV) species in model natural waters in dependence of pe and $\mathrm{pH}$.

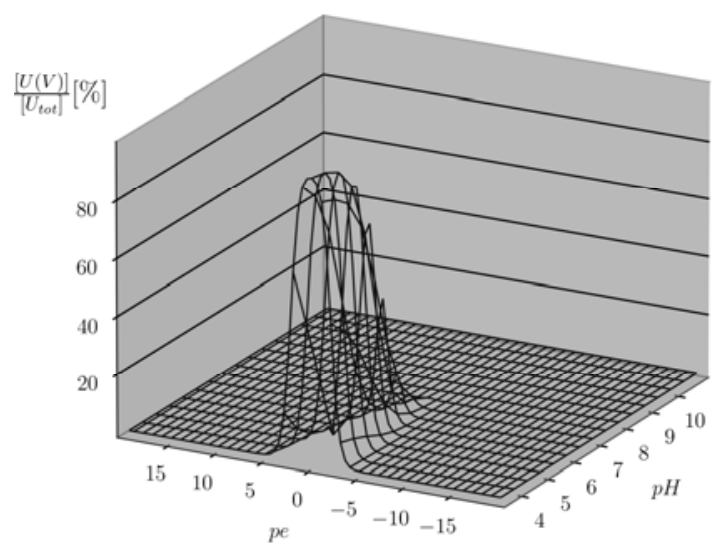

Fig. 3. Proportion of $U(V)$ species in model natural waters in dependence of pe and $\mathrm{pH}$.

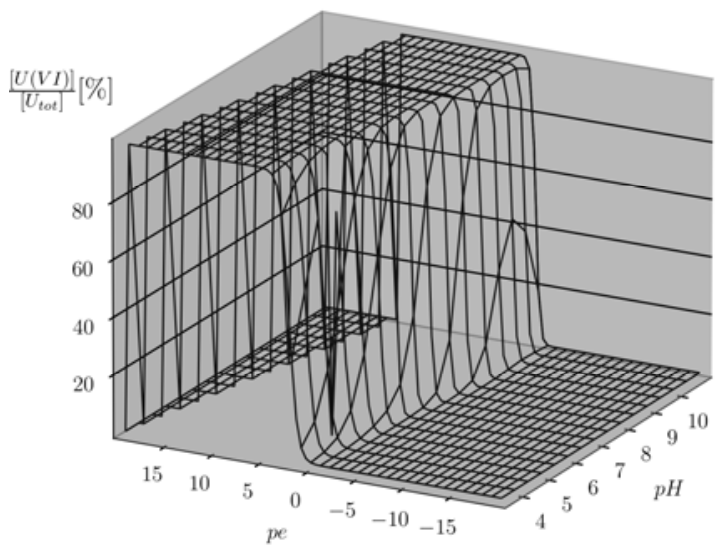

Fig. 4. Proportion of U(VI) species in model natural waters in dependence of pe and $\mathrm{pH}$. 


\section{Materials and methods}

\subsection{Sediment and water sampling, sample site and sample points}

The sampling of the investigated sediments and water has been performed on November 20, 2008 according to ISO 5667-12 (Guidance on sampling of bottom sediments) and ISO 5667-15 (Guidance on the preservation and handling of sludge and sediment samples). The sample site has been chosen in close proximity of a former uranium mine adit in Považský Inovec mountain range (Fig. 5).

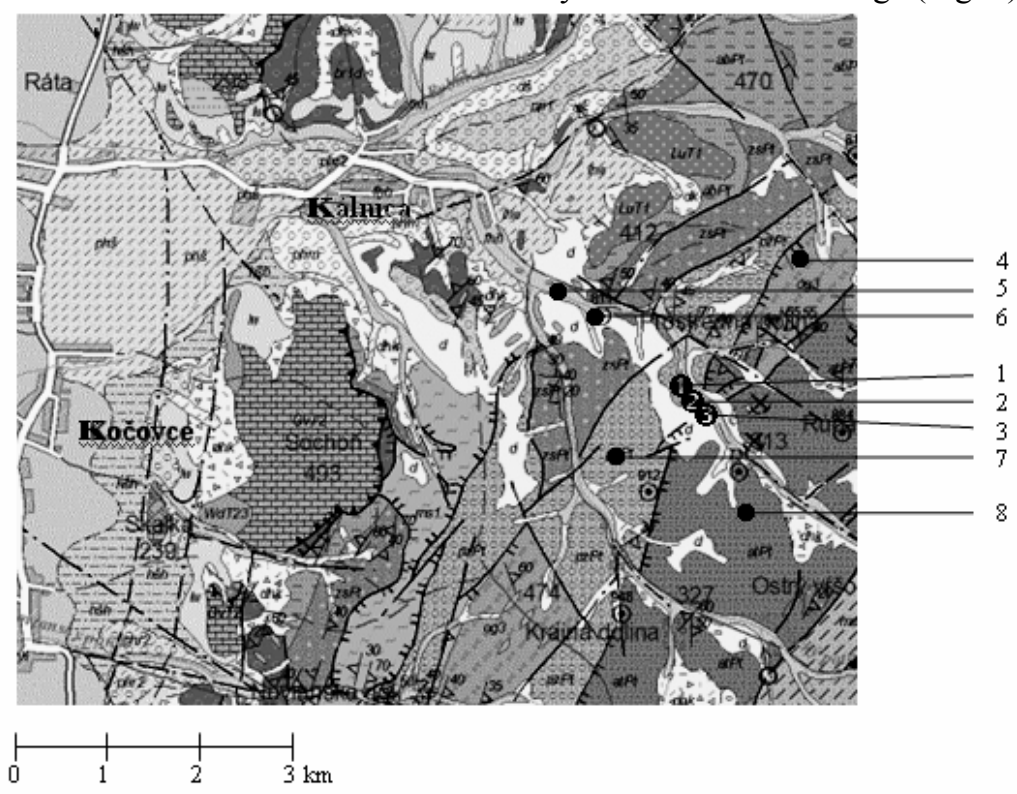

Fig. 5. Geological map of Kálnica Uranium deposition surroundings with sampling points.

1- sampling point 1,2-sampling point 2,3-sampling point 3,

4 crystalline basement, Devonian, pale "augengneissis",

5- Quaternaiy undivide fluvial sediments,

6- Quatemary lithofacial undivided slope debris and screes,

7- Carboniferous arkosic and greywacke sandstones, polymict conglomerates,

8- Permian, Selec formation, conglomerates, greywacke, greywacke sandstones,

siltstones.

Uranium mineralization in Perm of Považský Inovec Mts. (Kálnica, Selec) is stratiform type (ROJKOVIČ, 1980; IVANIČKA et al., 2007). Major elements of mineralization act in psammitic and psefitic rocks. Increased accumulation of uranium and accompanying minerals arose due to clastic material acquisition and by precipitation from aqueous solution. An important source of uranium was volcanisms of quartz porphyry and partly exposed crystalline rocks. During sedimentation and diagenesis in the productive complex of strata occurred the accumulation of uranium and accompanying minerals and during the Alpine orogeny their concentration in the form of lenses. The most common ore minerals are pyrite, uraninite and rutile. The main elements of mineralization are $\mathrm{U}, \mathrm{Pb}, \mathrm{Cu}, \mathrm{Mo}$ 
and coincident elements $\mathrm{Ni}$, Co and partly Y and V. Sampling point 3 (N 48 $44.81^{\prime}$; E $17^{\circ} 57.68$ ) has been chosen directly at the groundwater outflow from the uranium mine, which flows to the stream Prostredný potok. Sampling points 2 (N 48 $44.80^{\prime}$; $\left.\mathrm{E} 17^{\circ} 57.68\right)$ and $1\left(\mathrm{~N} 48^{\circ} 44.22^{\prime}\right.$; E 17 $\left.7^{\circ} 57.32\right)$ have been chosen at the above mentioned stream, approx. 25 and $50 \mathrm{~m}$ respectively north-west from the outflow.

\subsection{Physical-chemical characterization of the sediment-water system}

The primary characterization of the investigated system - the measuring of the water column height, the $\mathrm{pH}$ and Eh of water and sediment, the thickness of the sediment and the definition of the sediment colour have been accomplished in situ. The additional assays - the $\mathrm{pH}$ determination of the water- as well as the $0.01 \mathrm{~mol} \mathrm{dm}^{-3} \mathrm{CaCl}_{2}$ extracts of the sediments, the sediments dry matter determination, the measuring of the water conductivity, the sedimentation test (for the sample taken at sampling point 3 ) as well as the granulometric analysis (for the sample taken at sampling point 1) - have been accomplished in the laboratory. The sedimentation test has been realized with $20 \mathrm{~g}$ air dry sediment in $100 \mathrm{~cm}^{3}$ graduated cylinder. For the wet granulometric analysis (utilizing water taken at the identical sampling point) $2.0 \mathrm{~mm}, 1.0 \mathrm{~mm}, 0.25 \mathrm{~mm}, 0.125 \mathrm{~mm}$ and 0.06 sieves have been applied and the fractions have been weighed after drying at laboratory temperature. The mineralization of the samples (sediments from sampling points 2 and 3 as well as the reference sediment GBW 07306) has been executed using the microwave sample digestion system MULTIWAVE 3000 (ANTON PAAR, AUSTRIA). $0.25 \mathrm{~g}$ air dry sediments have been treated with $5 \mathrm{~cm}^{3}$ conc. $\mathrm{HNO}_{3}$ and $2 \mathrm{~cm}^{3}$ conc. $\mathrm{H}_{2} \mathrm{SO}_{4}$ at $\mathrm{T}_{\max }=496 \mathrm{~K}$ and $\mathrm{P}=2.6 \cdot 10^{6} \mathrm{~Pa}$ (sediment 2 and GBW 07306) as well as $\mathrm{T}_{\max }=449 \mathrm{~K}$ and $\mathrm{P}=1.36 .10^{6} \mathrm{~Pa}$ (sediment 3). The total uranium concentrations in mineralized sediments have been determined by ICP-MS (HP 4500, HEWLETT PACKARD, USA) utilizing ICP-MS VI (MERCK) calibration solutions and certified reference sediment TMDA 62 (NATIONAL WATER RESEARCH INSTITUTE, CANADA). The uranium concentrations in particular fractionation extracts have been determined by spectrophotometry according STN 75 7614 (Water quality. Determination of uranium), using UV-VIS spectrophotometer CARY 50 BIO, VARIAN, AUSTRALIA. The extraction fractionations of the sediments have been accomplished applying a slightly modified Tessier type sequential extraction procedure.

In order to study the influence of oxygen to the uranium mobility in the watersediment system we realized a time dependent aeration of investigated materials in contact with uranium contaminated water. $1 \mathrm{~g}$ of air dry sediment 3 has been placed in a test-tube and $8 \mathrm{~cm}^{3}$ of water has been added. To $1 \mathrm{~g}$ of sediment 2 and montmorillonite K-10 placed in the same type of test-tubes $8 \mathrm{~cm}^{3}$ of uranium acetate solution (uranium concentration $12 \mathrm{mg} \mathrm{dm}^{-3}$ ) has been added. Using a simple laboratory aeration apparatus a time dependent aeration (1h, 1 day, 1 week) has been accomplished and after centrifugation (4000 rpm, $300 \mathrm{~s}$ ) the modified Tessier type sequential extraction has been carried out. The same experiment has been fulfilled, using argon atmosphere. 


\section{Results and discussion}

The obtained results of the primary characterization of the investigated system are shown in Table 1 (in situ determinations) and in Table 2 (laboratory determinations).

Table 1. In situ determinations. H: water column height, TH: sediment thickness, COL: sediment colour, * water sampling points identical with $1,2,3$ sediment sampling points.

\begin{tabular}{|c|c|c|c|c|c|}
\hline & $\mathbf{H}[\mathbf{c m}]$ & TH $[\mathrm{cm}]$ & COL & $\mathbf{p H}\left(25^{\circ} \mathrm{C}\right)$ & pe \\
\hline Sediment 1 & 2 & 7.5 & Grey & - & $\longrightarrow$ \\
\hline Sediment 2 & 2 & 7.5 & brown & - & $\longrightarrow$ \\
\hline Sediment 3 & 2 & 7.5 & orange & - & $-0.76\left(8.7^{\circ} \mathrm{C}\right)$ \\
\hline Water $1^{*}$ & - & - & $\ldots$ & 8.15 & $\begin{array}{c}+2.96 \\
\left(7.4^{\circ} \mathrm{C}\right)\end{array}$ \\
\hline Water 2* & - & - & - & 7.86 & $\begin{array}{l}+1.59 \\
\left(7.5^{\circ} \mathrm{C}\right)\end{array}$ \\
\hline Water $3^{*}$ & - & - & - & 7.40 & $\begin{array}{l}+0.35 \\
\left(8.7^{\circ} \mathrm{C}\right)\end{array}$ \\
\hline
\end{tabular}

Table 2. Laboratory determinations. D: dry substance.

\begin{tabular}{|c|c|c|c|c|}
\hline & \multirow{2}{*}{$D\left(1 \mathrm{~h},{\left.105^{\circ} \mathrm{C}\right)}^{-1}\right.$} & \multicolumn{2}{|c|}{ Extract pH } & \multirow{2}{*}{$\chi\left[\mu \mathrm{S} \mathrm{cm}^{-1}\right]$} \\
\hline & & $\mathrm{H}_{2} \mathrm{O}$ & $0.01 \mathrm{MCaCl}_{2}$ & \\
\hline Sediment 1 & $74.95 \%$ & 7.33 & 6.93 & - \\
\hline Sediment 2 & $72.69 \%$ & 7.90 & 7.52 & - \\
\hline Sediment 3 & $13.26 \%$ & 7.85 & 7.42 & - \\
\hline Water $1^{*}$ & - & - & 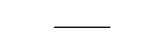 & $773\left(17.9^{\circ} \mathrm{C}\right)$ \\
\hline Water $2^{*}$ & - & - & - & $887\left(18.3^{\circ} \mathrm{C}\right)$ \\
\hline Water $3^{*}$ & - & - & - & $873\left(18.7^{\circ} \mathrm{C}\right)$ \\
\hline
\end{tabular}

Moving away from the outflow we observed moderately increasing $\mathrm{pH}$ values of water, slightly decreasing $\mathrm{pH}$ values of $0.01 \mathrm{M} \mathrm{CaCl}_{2}$ sediment extracts, as well as increasing oxidation-reduction potential. The mentioned facts are obviously connected with decreasing dissolved $\mathrm{CO}_{2}$ - and increasing dissolved $\mathrm{O}_{2}$ concentrations as well as with the subsequent oxidation of several metal ions causing production of their precipitates.

Sedimentation curves of sediment 3 (not shown) confirm the apparent and simply distinguishable homogeneity of the clayey sediment, which even after 3 days did not show any tendency to swell.

The granulometric analysis of sediment 1 showed a substantial fraction, namely $56.8 \%$ of grains sized $>2 \mathrm{~mm}, 30.5 \%$ of the grain fraction $0.25-1.0 \mathrm{~mm}, \sim 4.7 \%$ of the grain fraction $0.25-0.125 \mathrm{~mm}$ and $\sim 4.5 \%$ of the grain fraction $0.125-0.06 \%$. According the recent knowledge (BREITNER et al., 2008) uranium is preferentially bound to the finest sediment grains and therefore the experiments connected with the sequential extractions have been fulfilled with samples of the grain fraction $0.125-$ $0.06 \mathrm{~mm}$. 
ICP-MS determinations of total uranium have been performed for groundwater outflow at sampling point 3, for sediment 2 and for sediment 3 in duplicate samples. We obtained the following results: $31.75 \pm 0.35 \mu \mathrm{g} \mathrm{dm}{ }^{-3}$ for groundwater outflow; $38.0 \pm 2.71 \mu \mathrm{g} \mathrm{g}^{-1}$ for sediment 3 and $9.0 \pm 0.59 \mu \mathrm{g} \mathrm{g}^{-1}$ for sediment 2 .

Uranium concentrations in particular fractions of sediment 2 and sediment 3 using the applied sequential extractions (modified Tessier type procedure) are shown in Table 3.

Table 3. Uranium concentrations in the investigated sediment fractions using modified Tessier type procedure. F0: water soluble fraction, F1: ion-exchangeable fraction, F2: carbonate-bound fraction, F3: $\mathrm{Fe} / \mathrm{Mn}$ oxides-bound fraction, F4: organic matter-bound fraction.

\begin{tabular}{ccc}
\hline \multirow{2}{*}{ Fraction } & \multicolumn{2}{c}{ Uranium concentration $\left[\mu \mathrm{g} \mathrm{g}^{-1}\right]$} \\
\cline { 2 - 3 } & Sediment 2 & Sediment 3 \\
\hline F0 & - & $1.550 \pm 0.533$ \\
F1 & - & $1.620 \pm 0.533$ \\
F2 & $0.789 \pm 0.725$ & $\mathbf{1 2 . 9 3 5 \pm 0 . 5 5 9}$ \\
F3 & $0.893 \pm 0.722$ & $1.113 \pm 0.658$ \\
F4 & - & $1.742 \pm 0.532$ \\
\hline
\end{tabular}

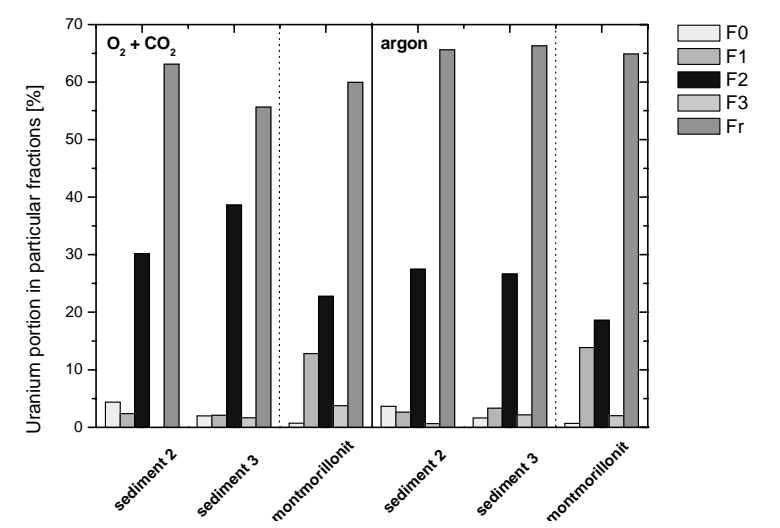

Fig. 6. Comparison of uranium fractionation in sediment samples and montmorillonite K-10 after 1 week aeration and argonation. F0: water soluble fraction, F1: ion-exchangeable fraction, F2: carbonate-bound fraction, $\mathrm{F} 3: \mathrm{Fe} / \mathrm{Mn}$ oxides-bound fraction Fr: residual fraction.

Considering the obtained results it is straightforward, that for sediment 3 the prevailing amount of uranium is in the carbonate-bound fraction. This finding is in accordance with the published papers (BUNZL et al., 1998 and MARTIN et al., 1998). For sediment 2 the same fraction markedly drops and in the same time the $\mathrm{Fe} / \mathrm{Mn}$ oxides-bound fraction become the most uranium containing one. The mentioned facts are with high probability connected to the quick aqueous $\mathrm{CO}_{2}$ concentration fall in the water as well as with a consequent uranium species sorption on the stream sediments. 
Via aeration/argonation experiments (outlined in section 3.2) we gained a valuable comparison of time dependent uranium fractionation in investigated sediments vs. in montmorrillonite K-10 with and without contact with air. Fig. 6 illustrates the obtained results after 1 week of aeration and argonation respectively.

\section{Conclusions}

While the proportion of U(III) species in uranium contaminated natural waters at pe -5 and $\mathrm{pH} 4$ hardly reach $1 \%$ and $\mathrm{U}(\mathrm{V})$ species exist only in relatively narrow pe and $\mathrm{pH}$ range, a considerable portion of uranium may exist in U(IV) oxidation state, namely at relatively low oxidation-reduction potential (pe values from -5 to 0 ) and the main portion in U(VI) oxidation state at positive pe values. The uranium concentration of the investigated water outflow from the former uranium mine adit reached as much

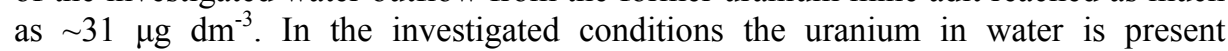
predominantly in $\mathrm{U}(\mathrm{VI})$ oxidation state. With raising distance from the spring the water has a tendency of increasing pe and decreasing $\mathrm{pH}$ values. In montmorillonite K-10 the carbonate-bound uranium fraction after 1 week of aeration reached $\sim 22 \%$. In aerated conditions uranium has been present in carbonate-bound fraction of investigated sediments in much higher concentration reaching $\sim 40 \%$. The presence of air in all cases gave rise to a measurable increase of uranium proportion in biologically available fractions. Compared to montmorillonite K-10, where the influence of air has been smaller, in similar conditions the biologically available uranium fractions unambiguously increased reaching 30-35\% after 1 week aeration.

Acknowledgements: We would like to express our sincere thanks to Dr. Adriana Shearman for accomplishing the ICP-MS determinations.

\section{References}

ZÁVODSKÁ, L., KOSORÍNOVÁ, E., ŠČERBÁKOVÁ, L., LESNÝ, J.: Environmental chemistry of uranium. HEJ, ENV-081221-A, 2008, 1-19.

SZABÓ-NAGY, A., ZÁVODSKÁ, L., MÁTEL, L., LESNÝ, J.: Geochemistry and determination possibilities of uranium in natural waters. Acta Tech. Jaurin., 2009, in press.

GREENWOOD, N.N., EARNSHAW, A.: Chemistry of the Elements. Second edition. Butterworth-Heinemann, Elsevier Science, Linacre House, Jordan Hill, Oxford OX2 8DP, 1997.

UNITED STATES GEOLOGICAL SURVAY: Phreeqc version 2.15.0, 2008.

BENJAMIN, M.M.: Water Chemistry. McGraw-Hill, Singapore, 2002.

MOREL, F.M.M., HERING, J.G.: Principles and Applications of Aquatic Chemistry. John Wiley \& Sons, USA, 1993.

GRENTHE, I., PIUGDOMENECH, I.: Modelling in Aquatic Chemistry. NEA\&OECD, France, 1997.

GUILLAUMONT, R., FANGHÄNEL, T., FUGER, J., GRENTHE, I., NECK, V., PALMER, D.A., RAND, M.H.: Update on the Chemical Thermodynamics of 
Uranium, Neptunium, Plutonium, Americium and Technetium. Chemical Thermodynamics, vol. 5, Elsevier, The Netherlands, 2003.

ROJKOVIČ, I.: Geochemická charakteristika uránového zrudnenia v perme Považského Inovca. Manuskript, Geofond Bratislava, 1980.

IVANIČKA, M., HAVRILA, M., KOHÚT, M. (Editors): Geologická mapa regiónu Považský Inovec a jv. časti Trenčianskej kotliny. 1:50 000, Štátny geologický ústav Dionýza Štúra, Bratislava, 2007.

BREINTNER, D., TURTIAINEN, T., ARVELA, H., VESTERBACKA, P., JOHANSON, B., LEHTONEN, M., HELLMUTH, K.H., SZABÓ, C.: Multidisciplinary analysis of Finnish esker sediment in radon source identification. Sci. Total Environ., 405, 2008, 129-139.

BUNZL, K., KRACKE, W., SCHIMMACK, W., ZELLES, L.: Forms of fallout ${ }^{137} \mathrm{Cs}$ and ${ }^{239+240} \mathrm{Pu}$ in successive horizons of forest soil. J. Environ. Radioact., 39, 1998, $55-68$.

MARTIN, R., SANCHEZ, D.M:, GUTIERREZ, A.M.: Sequential extraction of U, Th, $\mathrm{Ce}$, La and some heavy metals in sediments from Ortigas river, Spain. Talanta, 46, 1998, 1115-1121. 